\title{
Puyehue Cordón-Caulle: post-eruption analysis of changes in stream benthic fauna of Patagonia
}

\author{
Mailén Elizabeth Lallement ${ }^{1, ®}$; Santiago Martín JuáreZ; Patricio Jorge Macchi ${ }^{1}$ \& \\ PABlo Horacio VigLiano ${ }^{1}$
}

1. Universidad Nacional del Comahue, Grupo de Evaluación y Manejo de Recursos Ícticos, Bariloche, Argentina. 2. Instituto de Investigaciones en Biodiversidad y Medioambiente (INIBIOMA) - CONICET, Universidad Nacional del Comahue, Bariloche, Argentina

\begin{abstract}
Aвstract. Volcanic eruptions are natural phenomena with the most diverse and varied consequences, and have important effects on both terrestrial and aquatic environments. On June $4^{\text {th }}, 2011$ the volcanic Puyehue Cordón-Caulle complex (2.236 masl, $40^{\circ} 32^{\prime} \mathrm{S}-72^{\circ} 2^{\prime} \mathrm{W}$, Chile) erupted explosively ejecting on the first day, 950 million metric tons of ashes into the atmosphere. Due to predominant westerly winds, 24 million hectares of Argentinian Patagonia were covered by the ashfall. We studied three streams in northwestern Patagonia in order to explore the ash fall impact and possible recovery processes in water quality and macroinvertebrate communities. We selected three streams representing maximum, intermediate and minimum ash deposition levels. For each stream, we selected two sampling sites to measure $\mathrm{pH}$, conductivity, total dissolved solids (TDS), turbidity (NTU) and to take three macroinvertebrate samples during summer 2012 and 2013. After the eruption of the Puyehue-Cordón Caulle complex, substantial environmental changes were observed in association with the large amount of ash ejected by the volcano and deposited on the nearest areas. Low benthic fauna densities, as well as low values of Ephemeroptera, Plecoptera and Trichoptera (EPT) and Biotic Monitoring Patagonian Streams (BMPS) indexes, reflected changes in water quality due to ash fall, mainly in the two streams closer to the volcano. After eighteen months, the streams had not reached the density, taxa composition and structure of trophic webs comparable to other streams previously studied in the region. The exploratory analysis suggests that the main impact was a consequence of ash fall in terms of the amount and particle size proportions.
\end{abstract}

[Keywords: volcanic ash, impact, arthropods, functional feeding groups, water quality]

Resumen: Puyehue Cordón -Caulle: Cambios en la fauna bentónica de arroyos de Patagonia post-erupción: Las erupciones volcánicas son los fenómenos naturales con las consecuencias más variadas y complejas, y tienen efectos importantes en ambientes tanto terrestres como acuáticos. El 4 de junio de 2011, el complejo volcánico Puyehue Cordón-Caulle ( $2.236 \mathrm{msnm}, 40^{\circ} 32$ 'S, $72^{\circ} 2^{\prime} \mathrm{W}$, Chile) entró en erupción, eyectando el primer día 950 millones de toneladas de cenizas hacia la atmósfera. Debido al predominio de vientos del oeste, 24 millones de hectáreas de la Patagonia Argentina fueron cubiertas gradualmente de ceniza. Para explorar cómo se vieron afectados por la caída de ceniza arroyos del noroeste de Patagonia y los posibles procesos de recuperación de la calidad del agua y de las comunidades de macroinvertebrados bentónicos se seleccionaron tres arroyos. Los arroyos seleccionados correspondieron a tres niveles de depositación de ceniza (i.e. máximo, intermedio y mínimo). En cada arroyo se seleccionaron dos sitios de muestreo, donde se midieron: $\mathrm{pH}$, conductividad, sólidos totales disueltos (STD) y turbidez (NTU) y se tomaron muestras de macroinvertebrados durante los veranos de 2012 y 2013. Luego de la erupción volcánica se observaron cambios ambientales relacionados con la cantidad de ceniza eyectada y depositada en las áreas más cercanas al volcán. Cambios en la calidad del agua debido a la caída de ceniza se vieron reflejados en bajos valores de densidad, índices EPT (Ephemeroptera, Plecoptera y Trichoptera) y BMPS (Índice de Monitoreo Biótico de Arroyos de Patagonia), principalmente en los arroyos más cercanos al volcán. Luego de dieciocho meses, las densidades, composición de taxones y estructuras de tramas tróficas de los arroyos estudiados no fueron comparables con las de otros arroyos previamente estudiados en la región. El análisis exploratorio sugirió que el mayor impacto fue consecuencia de la deposición de ceniza en términos de cantidad y proporciones de tamaño de partícula.

[Palabras clave: ceniza volcánica, impacto, artrópodos, grupos funcionales, calidad del agua]

\section{INTRODUCTION}

Volcanic eruptions are natural phenomena, creating diverse and varied consequences which give place to a mosaic of environmental conditions (both in terrestrial and aquatic environments). The effect and magnitude of

Editora asociada: Adriana Ruggiero

maylallement@gmail.com eruptions depends on the scale of the event (Óskarsson 1980; Witham et al. 2005), having different physical impacts in association with the type of materials ejected (Annen \& Wagner 2003) and the extent of the deposit. Direct effects include alteration of biotic components and immediate massive habitat loss (Arendt et 
al. 1999). However, effects of lighter fractions, such as small ash particles that can disperse over thousands of kilometers (Martin et al. 2009) are less evident and less reported.

A variety of factors influences species survival after the ash fall such as life stories, recolonization mechanisms and dispersal strategies (Dale et al. 2005; Marske et al. 2007; Miserendino et al. 2012; Masciocchi et al. 2013), as well as the availability of safe sites and the characteristics of each affected environment (Death et al. 2003). Whereas, in some situations, volcanic events have benefited the spread of the biota, in other environments the biota was entirely eliminated (del Moral 1981). Mount Saint Helens eruption on southwestern US in 1980 is, perhaps, the most comprehensively studied eruption. After the ash fall, terrestrial insect populations were highly reduced due to the abrasive effects of volcanic ash (Edwards et al. 1986), meanwhile surviving colonies could not prosper due to the scarcity of resources left (del Moral 1981). In aquatic environments, suspended solid increased after the deposit of ejected materials, and it was observed even during several months after Mount St. Helens eruption (Antos \& Zobel 2005). Suspended solids in the water resulted in varying negative behavioral, physiological and mechanical responses in fishes (Redding et al. 1987). Also, there was a decrease in some taxa of macroinvertebrates, in relation to the instability of the substrate, which also affected recolonization processes (Anderson 1992).

The southern region of the Andes $\left(36^{\circ}-44^{\circ} \mathrm{S}\right.$, $72^{\circ} \mathrm{W}$ ) has approximately 50 active volcanoes (Besoain 1985), which to a greater extent have shaped the landscape and have also been responsible for structuring biotic communities in the region (Ruzzante \& Rabassa 2011). On June $4^{\text {th }}, 2011$ the volcanic complex Puyehue Cordón- Caulle erupted (2.236 masl, 40 ${ }^{\circ} 32^{\prime}$ S-72 ${ }^{\circ}{ }^{\prime} \mathrm{W}$, Chile), liberating on the first day of the eruption about 950 million metric tons of ejecta into the atmosphere and generating an ash cloud $14,000 \mathrm{~m}$ in height. Due to the prevalence of westerly winds, 24 million hectares of Patagonia were covered with ash (Gaitán et al. 2012). Around $15 \mathrm{~cm}$ of ash fell upon the small town of Villa La Angostura, $54 \mathrm{~km}$ SE from the volcano emission point, whereas between 3-4.5 cm of ash were deposited in San Carlos de Bariloche city a $100 \mathrm{~km}$ away (Wilson et al. 2012). The lighter material was carried by the wind for thousands of miles over several months, diversely affecting different environments. This event impacted, both, terrestrial (Buteler et al. 2011; Masciocchi et al. 2013) and aquatic communities (Lallement et al. 2012; Modenutti et al. 2013; Wolinski et al. 2013).

Invertebrates play an important role in aquatic ecosystems as part of the functional processes, providing a link between the base of the food web and high trophic levels (Jackson \& Fisher 1986; Gray 1989, 1993). Knowledge about invertebrate assemblages in aquatic systems allows the evaluation of their community dynamics, trophic relationships with fish and disturbances (Wiederholm 1984). The present paper aims to explore the impact of differing levels of ash deposition and possible post event processes of benthic macroinvertebrates and water quality in three streams of northwestern Patagonia (Argentina). Specifically, we evaluated whether the stream water parameters measured during two summers after the eruption (in 2012 and 2013) approached the pre-eruptive values (recorded in 2007), and whether the spatial and temporal variation in the density of organisms and number of taxa increased with distance from the volcano and time since the eruption.

\section{METHODS}

\section{Study area}

Three Andean lotic environments were selected within the Nahuel Huapi National Park in northwestern Patagonia (Argentina): Acantuco, La Estacada and Castilla $\left(40^{\circ} 08^{\prime}\right.$ and $41^{\circ} 35^{\prime} \mathrm{S}$ and $71^{\circ} 02^{\prime} 71^{\circ} 57^{\prime} \mathrm{W}$ ); an environmental characterization is presented in Table 1. Annual precipitation

Table 1. Environmental characterization of the studied streams across the ashfall gradient.

Tabla 1. Caracterización ambiental de los arroyos estudiados a lo largo del gradiente de ceniza caída.

\begin{tabular}{lcccccccc}
\hline & $\begin{array}{c}\text { Mean Elevation Distance from } \\
(\text { masl })\end{array}$ & $\begin{array}{c}\text { Basin } \\
\text { the Volcano } \\
(\mathrm{km})\end{array}$ & $\begin{array}{c}\text { Area } \\
\left(\mathrm{km}^{2}\right)\end{array}$ & $\begin{array}{c}\text { Main } \\
\text { channel } \\
\text { slope }(\%)\end{array}$ & $\begin{array}{c}\text { Mean } \\
\text { Current } \\
\text { Flow }(\mathrm{m} / \mathrm{s})\end{array}$ & $\begin{array}{c}\text { Mean } \\
\text { Discharge } \\
\left(\mathrm{m}^{3} / \mathrm{s}\right)\end{array}$ & $\begin{array}{c}\text { Channel } \\
\text { Mean } \\
\text { depth }(\mathrm{m})\end{array}$ & Sinuosity \\
\hline Acantuco & 997 & 30 & 18.25 & 60.28 & 0.32 & 721 & 0.21 & 0.67 \\
Estacada & 1145 & 60 & 48.35 & 44.97 & 0.25 & 303 & 0.14 & 0.85 \\
Castilla & 818 & 83 & 25.21 & 19.97 & 0.17 & 119 & 0.16 & 0.80 \\
\hline
\end{tabular}




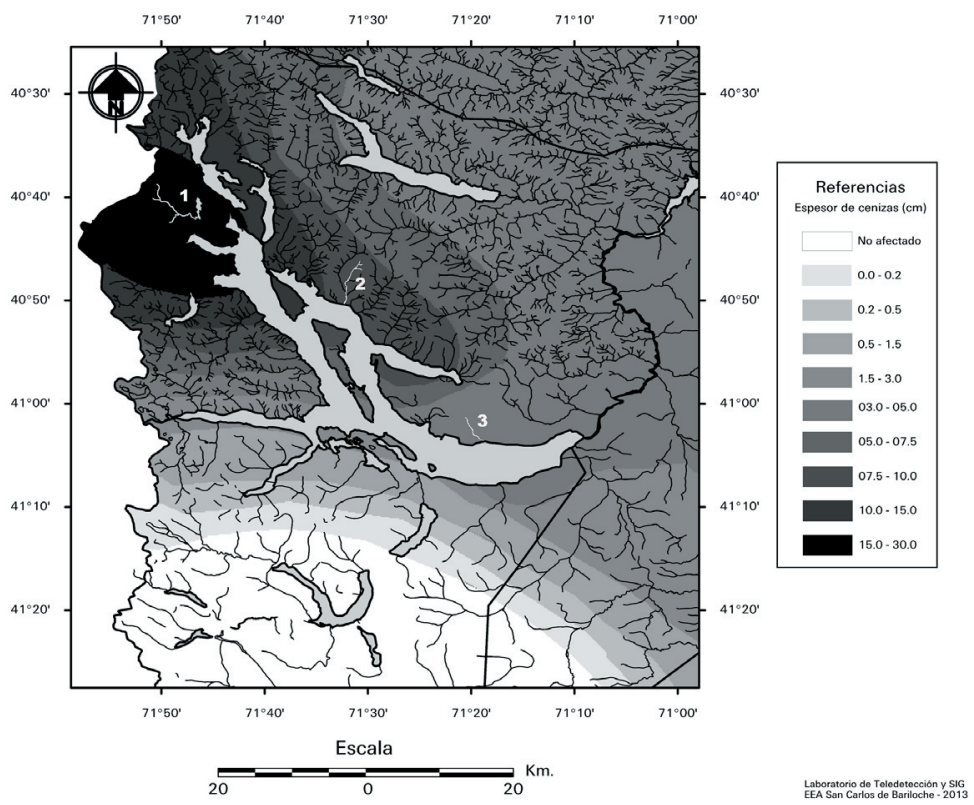

Figure 1. Sampled streams $(1=$ Acantuco, 2= La Estacada, 3= Castilla) and height of fallen ash $(\mathrm{cm})$ along the west-east gradient (Gaitán et al. 2012).

Figura 1. Arroyos muestreados (1= Acantuco, 2= La Estacada, 3= Castilla) y altura de la capa de ceniza $(\mathrm{cm})$ depositada a lo largo del gradiente oeste-este (Gaitán et al. 2012).

decreases from west to east from 4000 to $500 \mathrm{~mm}$ creating a climatic gradient (Paruelo et al. 1998), and allowing for a variety of both terrestrial and aquatic habitats as well as varying plant and animal assemblages The region has a profound history of volcanic eruptions, which has been recorded in the tephra deposits that can be found all over the region (Villarosa et al. 2006). The eruption of June $4^{\text {th }} 2011$ caused a gradient of ash deposition in the study area, due to the presence of this environmental gradient, the predominant westerlies and the volcano location (Figure 1).

\section{Sampling Design}

We selected three streams, which corresponded to maximum, intermediate and minimum ash deposition levels (i.e. 30.0 / 7.5-10/ $3.0 \mathrm{~cm}$ respectively) according to data recorded by Gaitán et al. (2012) (Figure 1). We sampled the streams during the summers of 2012 and 2013, although we conducted an exploratory sampling in the Acantuco stream (the closest point to the emission center) in November 2011, which showed that dissolved oxygen (DO) was at saturation levels. The same pattern with respect to DO was reported in several other streams and given that the ash fall did not change metal concentrations in water (Caneiro et al. 2011; Carignano et al. 2011; Beamud et al. 2012) no further analyses were done to determine them on the sampled streams. On each stream, two sampling sites were selected: one close to the stream outlet and the other upstream, where riparian forest composition varied.

Because the three streams we studied were affected by the ash fall and the pre-eruptive richness and taxonomic composition of their benthic macroinvertebrate assemblages were unknown, the present study lacked temporal

and spatial controls, which imposed serious limitations to infer causal effects of ash deposit on the structure and composition of benthic macroinvertebrate communities (see Hurlbert 1984). Thus, our study should be considered only as providing an exploratory approach to evaluate the possible consequences of ash fall on the studied communities. We relied only on the analysis of the temporal variations in macroinvertebrate benthic assemblages since the time of the eruption onwards although we did have pre-eruptive data (obtained in 2007 , see below) on water quality parameters. Then, to discuss possible recovery processes after the eruption we evaluated whether the stream water parameters measured in 2012 and 2013 approached the values recorded in 2007. On the other hand, we predicted that the density and number of taxa would increase with distance from the volcano and with time since the eruption, i.e. with the highest density and richness expected in Castilla and the lowest density and richness in Acantuco.

\section{Environmental characterization and macroinvertebrates collection and analysis}

In all samplings a series of environmental variables thought to have direct incidence on benthic organisms were recorded: $\mathrm{pH}$, conductivity $(\mu \mathrm{S} / \mathrm{cm})$, total dissolved solids (TDS, mg/l), and turbidity (in Nephelometric Turbidity Units, NTU's) values were measured and compared with data from samples taken in 2007 in the same sampling sites.

To perform a quantitative analysis of macroinvertebrate samples we followed Albariño's methodology (1994). Sampling sites were located at third order segments in each stream; in each sampling site three randomly placed replicates were taken. In all cases, special care was taken to sample a homogeneous sector of the stream in terms of substrate size and habitat type (i.e. riffles). Samples 
Table 2. Percentage of coarse sand ash-like particles in stream beds (2012-2013) and water quality parameters pre (2007) and post eruption (2012-2013). ND: No Data available.

Tabla 2. Porcentaje de arena en el lecho de los arroyos (2012-2013) y parámetros de calidad de agua pre (2007) y post erupción (2012-2013).

\begin{tabular}{|c|c|c|c|c|c|c|c|c|c|c|c|c|c|}
\hline \multirow[t]{2}{*}{ Stream } & \multicolumn{2}{|c|}{$\%$ Coarse sand ash } & \multicolumn{3}{|c|}{ Conductivity $\mu \mathrm{S} / \mathrm{cm}$} & \multicolumn{3}{|c|}{$\mathrm{pH}$} & \multicolumn{3}{|c|}{ TDS mg/1 } & \multicolumn{2}{|c|}{ NTU } \\
\hline & 2012 & 2013 & 2007 & 2012 & 2013 & 2007 & 2012 & 2013 & 2007 & 2012 & 2013 & 2012 & 2013 \\
\hline Acantuco & 98 & 50 & 44.4 & 74.9 & 65.7 & 7.63 & 8.35 & 7.83 & 31.9 & 53.3 & 41.5 & 99.5 & 4.05 \\
\hline Estacada & 60 & 30 & ND & 54.4 & 61.7 & 7.37 & 8.41 & 8.13 & 30 & 40.35 & 43.2 & 85.9 & 1.07 \\
\hline Castilla & 20 & 2 & 75.9 & 122.7 & 92.6 & 7.52 & 8.46 & 8.4 & 53.4 & 88.85 & 65.8 & 1.05 & 0.69 \\
\hline
\end{tabular}

were collected using a Surber sampler $\left(0.09 \mathrm{~m}^{2} ; 250\right.$ $\mu \mathrm{m}$ pore size). Samples were initially fixed with $4 \%$ formaldehyde solution and examined later in the laboratory separating and identifying organisms to the family level using regional keys (Dominguez \& Fernandez 2009).

To evaluate the eruption impact and possible recovering processes in each stream, a series of descriptors of the macroinvertebrate community were calculated for each site and sampling date. Taxa richness was measured as the number of families and density as the number of organisms per $\mathrm{m}^{2}$ in each sampling date. Mann Whitney tests were performed to compare differences in densities between years (2012-2013). In order to evaluate environmental conditions in each stream the Ephemeroptera, Plecoptera, Trichoptera index (EPT) was calculated. This index has been used as an indicator of water quality in Patagonian streams (Miserendino \& Pizzolón 2000) and is the ratio between the number of individuals belonging to the three orders and the number of all individuals in the sample (\% abundance EPT $=$ number of EPT specimens /Total Number of specimens) (Carrera \& Fierro 2001.) An adaptation of the BMWP index (Biological Monitoring Working Party Index, Armitage et al. 1983) for Patagonia devised by Miserendino \& Pizzolón (1999) (BMPS-Biotic Monitoring Patagonian Streams) was also calculated. The BMPS index is used to detect the effect of sedimentation processes upon aquatic communities (Miserendino 2007), using a table of 95 families with varying degree of tolerance to pollution (from 1 -10) present in Patagonia. The total BMPS score ranges from 0 to $>150(<15$ : strongly polluted water; 16-35: polluted waters; $36-60$ : probably polluted waters; 61-100: probably incipient pollution; >101: unpolluted waters; >150: very clean waters).

To explore families-environmental relationships in habitats at all streams sites, a Canonical correspondence analysis (CCA) was performed using CANOCO version 4.3. We used only three variables (TDS, $\%$ coarse sand ash \& NTU) due to multicolinearity between variables (Ter Braak \& Smilauer 1998). The significance of the relationships was tested using a Monte Carlo test (Jckel 1986).

\section{RESULTS}

\section{Environmental Changes}

Main visible effect of ash deposition was its accumulation on riparian vegetation and stream beds as well as changes in water quality parameters (Table 2). Three months after the eruption, the Acantuco stream (only $30 \mathrm{~km}$ away from the volcano) had

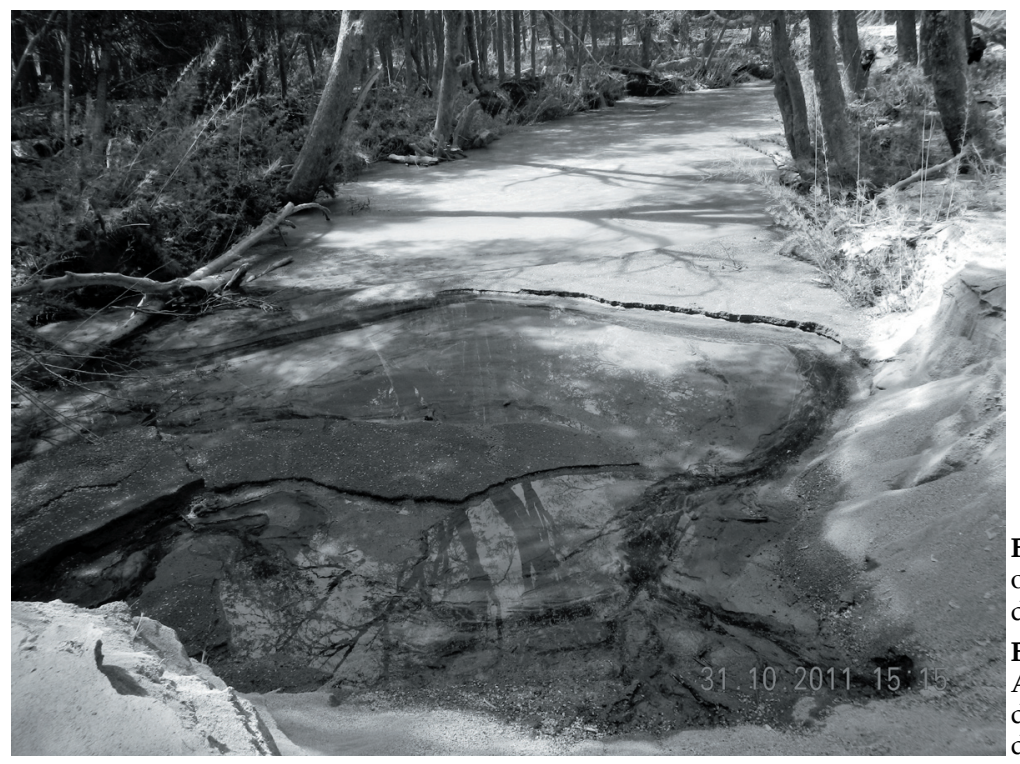

Figure 2. Main channel deactivation of the Acantuco stream due to ash deposition. October 2011.

Figura 2. Canal principal del arroyo Acantuco desactivado debido a la depositación de ceniza, Octubre de 2011. 
suffered major channel modifications which included damming by ash and woody debris, channel bed obliteration by ash deposition, deactivation of some channels and formation of new ones through the surrounding forest (Figure 2). In summer of 2012 (seven months after the eruption), $\mathrm{pH}$ values, as well as those of TDS and conductivity were higher than those recorded in summer 2007 (Table 2). Turbidity expressed in nephelometric units and the percentage of coarse sand

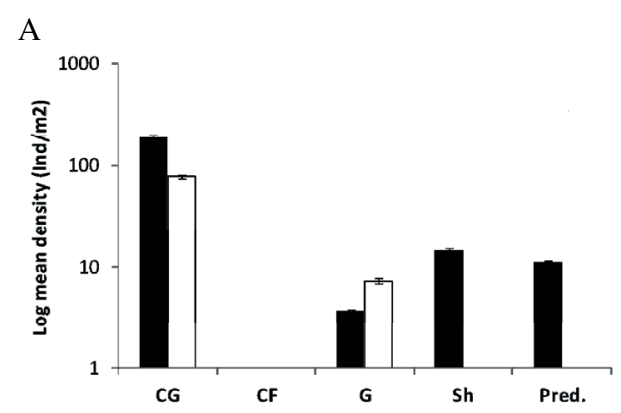

B
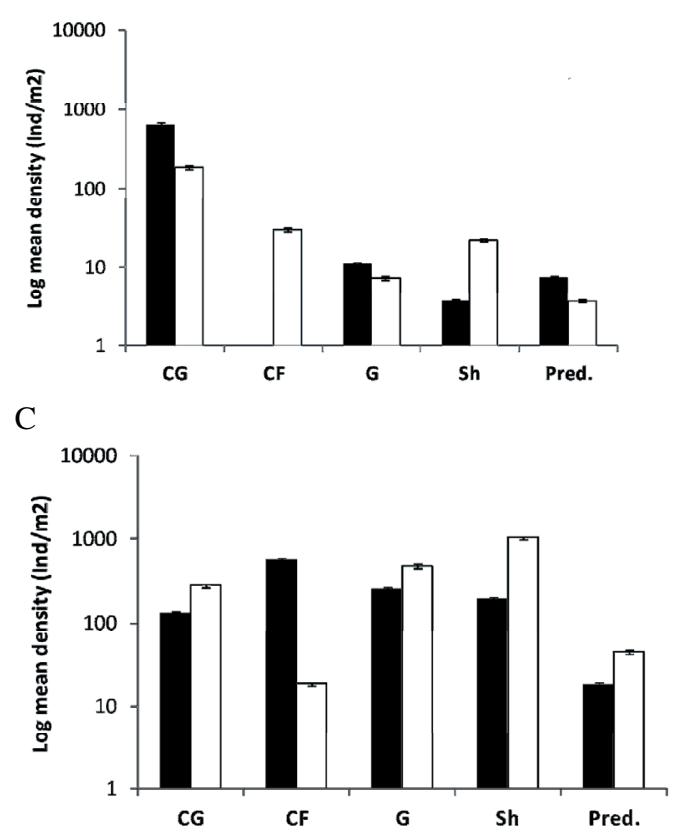

Figure 3. Mean density (logarithmic scale) of individuals per square meter and percentage average error. Black bars correspond to 2012 and white bars to 2013. Sh.: shredders; Graz.:grazers; Pred.: predators; C.F.: collectors-filterer; CG.: collector-gatherer. A. Acantuco, B. La Estacada, C. Castilla.

Figura 3. Densidad media (en escala logarítmica) de individuos por metro cuadrado y error promedio porcentual. Barras negras corresponden a 2012 y barras blancas a 2013. Sh.: trituradores; Graz.:pastoreadores; Pred.: predadores; C.F.: colectores-filtradores; CG.: colectores-recolectores. A. Acantuco, B. La Estacada, C. Castilla. like ash particles was high in all streams in accordance with the gradient of ash deposition described (Table 2). By summer 2013, values of all considered variables decreased being intermediate between those recorded in 2007 and 2012 (Table 2). However, the streams closest to the volcano kept high percentages of coarse sand like ash in their channels.

\section{Macroinvertebrates}

The total number of taxa varied greatly in each of the studied streams. The macroinvertebrate assemblages in the summer of 2012 were represented by a total of 4,6 and 18 taxa for the Acantuco, Estacada and Castilla respectively. In the summer of 2013, the number of taxa present was 2, 8 and 17 respectively (Table 3 ). No Trichoptera, Chilinidae or Crustacea were found in Acantuco or La Estacada in 2012 or 2013, Oligochaeta and Plecoptera were absent only in Acantuco. All these taxa were always present in Castilla. The number of families in Acantuco and La Estacada was lower than 50 $\%$ of that found in Castilla during the same period. Only two families, Leptophlebiidae (Order Ephemeroptera) and Chironomidae (Order Diptera), were found in all streams and samples.

Castilla showed the highest density values for all sample dates. The two streams closest to the volcano showed a decrease in total macroinvertebrate density from 2012 to 2013 (MW; $P=0.05 ; \mathrm{n}=6$ ). Organisms with higher densities were: in Acantuco: Chironomidae (in both years), in La Estacada: Chironomidae in 2012 and Oligochaeta in 2013 and in the Castilla: Simulidae and Leptophlebidae in 2012 and Elmidae, Leptophlebidae, Gripopterygidae, Chilinidae and Chironomidae in 2013.

Values found for the EPT index summarized in Table 3, show that the closest streams to the volcano had the lowest values in 2012, increasing in 2013. In the Castilla stream values were much higher, showing also an increase from one year to the other (Table 3).

For Acantuco, the BMPS in 2012 corresponds to polluted waters; in 2013 the value reflected a condition of strongly polluted waters (Table 3). For La Estacada, the BMPS for the first year corresponded to polluted water, and changed to probably polluted waters in 2013 (Table $3)$, whereas for Castilla the BMPS always corresponded to unpolluted waters (Table 3). 
Table 3. Density of Macroinvertebrate taxa, richness, functional groups, EPT and BMPS indexes found in all streams during 2012 and 2013. Sh.: Shredders; Graz: Grazers; Pred.: Predators; C.F.: Collectors-Filterer; CG.: Collector-Gatherer.

Tabla 3. Densidad de taxa de macroinvertebrados, riqueza, grupos funcionales e índices EPT y BMPS en los arroyos durante 2012 y 2013. Sh.: Trituradores; Graz.: pastoreadores; Pred.: Predadores; C.F.: Colectores-Filtradores; CG.: Colector-Recolector

\begin{tabular}{|c|c|c|c|c|c|c|c|}
\hline \multirow[b]{3}{*}{ Taxa } & \multirow[b]{3}{*}{ Functional Group } & \multicolumn{4}{|c|}{ Sampled Sites } & \multirow{2}{*}{\multicolumn{2}{|c|}{ Castilla }} \\
\hline & & \multicolumn{2}{|c|}{ Acantuco } & \multicolumn{2}{|c|}{ La Estacada } & & \\
\hline & & 2012 & 2013 & 2012 & 2013 & 2012 & 2013 \\
\hline \multicolumn{8}{|l|}{ Annelida } \\
\hline Oligochaeta & CG & & & 3.7 & 103.7 & 85.19 & 96.3 \\
\hline Hirudinea & Pred. & & & & & & 3.7 \\
\hline \multicolumn{8}{|l|}{ Mollusca } \\
\hline Chilinidae & Sh. & & & & & 48.15 & 188.9 \\
\hline \multicolumn{8}{|l|}{ Crustacea } \\
\hline Aeglidae & Graz. & & & & & 11.11 & \\
\hline Amphipoda & Sh. & & & & & 3.7 & \\
\hline \multicolumn{8}{|l|}{ Ephemeroptera } \\
\hline Leptophlebiidae & Graz. & 3.7 & 7.4 & 7.4 & 7.4 & 200 & 411.11 \\
\hline Baetidae & Graz. & & & & & 25.92 & 14.8 \\
\hline \multicolumn{8}{|l|}{ Plecoptera } \\
\hline Austroperlidae & Sh. & & & 3.7 & 11.11 & 11.11 & \\
\hline Gripopterygidae & Sh. & & & & 3.7 & 96.3 & 237 \\
\hline Notonemouridae & Sh. & & & & & & 40.7 \\
\hline \multicolumn{8}{|l|}{ Trichoptera } \\
\hline Calamoceratidae & Sh. & & & & & 3.7 & \\
\hline Hydroptilidae & Graz. & & & & & 14.8 & 11.1 \\
\hline Philopotamidae & $\mathrm{CF}$ & & & & & 3.7 & \\
\hline Helicophidae & Graz. & & & & & 11.1 & 48.1 \\
\hline Sericostomatidae & Sh. & & & & & 3.7 & 3.7 \\
\hline Ecnomidae & $\mathrm{CF}$ & & & & & 3.7 & \\
\hline Hydrobiosidae & Pred. & & & & & & 22.2 \\
\hline Glossosomatidae & Graz. & & & & & & 3.7 \\
\hline \multicolumn{8}{|l|}{ Coleoptera } \\
\hline Elmidae & Sh. & 3.7 & & & & 37.03 & 562.9 \\
\hline \multicolumn{8}{|l|}{ Diptera } \\
\hline Chironomidae & CG & 188.9 & 77.8 & 644.4 & 81.48 & 44.4 & 185.2 \\
\hline Tipulidae & Pred. & 11.1 & & & 7.41 & 11.11 & \\
\hline Ceratopogonidae & Pred. & & & 3.7 & & & \\
\hline Pelecorhynchidae & Pred. & & & 3.7 & & & \\
\hline Emphididae & Pred. & & & & 3.7 & & \\
\hline Simuliidae & $\mathrm{CF}$ & & & & 3.7 & 548.15 & 14.8 \\
\hline Athericidae & Pred. & & & & & & 11.1 \\
\hline Muscidae & $\mathrm{CF}$ & & & & & & 7.4 \\
\hline Total & & 207.4 & 85.2 & 666.6 & 222.2 & 1162.87 & 1862.71 \\
\hline Richness & 27 & 4 & 2 & 6 & 8 & 18 & 17 \\
\hline EPT & & 2 & 8.7 & 2 & 10 & 32 & 43 \\
\hline BMPS & & 22 & 12 & 23 & 43 & 109 & 117 \\
\hline
\end{tabular}

Functional groups as defined by Merrit \& Cummins (1978) varied in all streams from one year to the other (Table 3). In 2012, each one of the four functional groups (grazers, shredders, predators and collector-gatherers) recorded in Acantuco was represented by one taxonomic family; however, in 2013, functional groups diversity was reduced to only one family of grazers and another of collector-gatherers. Collectors-gatherers were always the most dominant in terms of density. Collector-filterers were absent in both years (Figure 3A). In 2012, La Estacada, showed one family in each one of three functional groups collected (grazers, shredders and collector-gatherers) and two families of predators; collector-filterers were absent. In 2013, all functional groups were present, and some of them were represented by several taxonomic families (Table 2). In both sampling dates, the collector-gatherers were the most dominant group (Figure 3B). In Castilla, all functional groups were present 

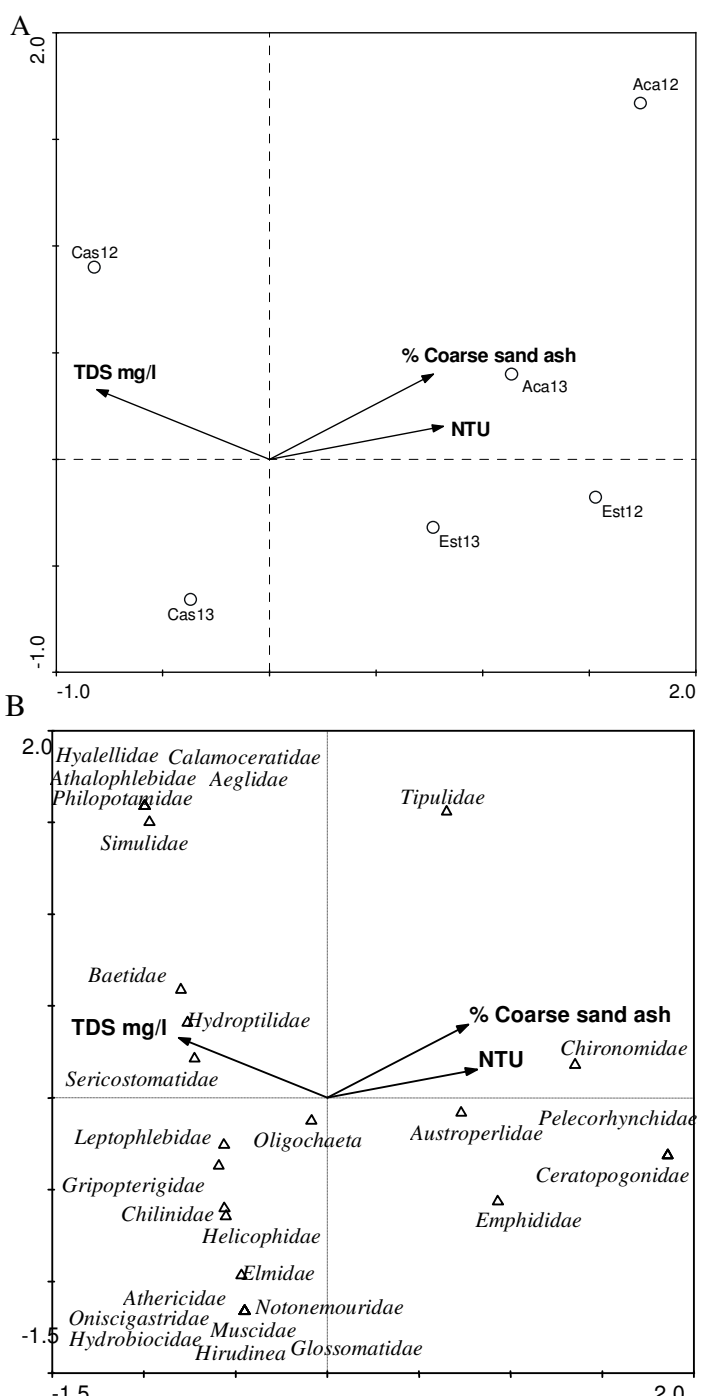

Figure 4. Canonical correspondence analysis for $\mathrm{A}$ : stream sites and environmental variables and B: stream macroinvertebrate families (abundance of individuals) and environmental variables.

Figura 4. Análisis de Correspondencia Canónica para A: arroyos y características ambientales y B: familias de macroinvertebrados (abundancia de individuos) y las variables ambientales.

in both years, with taxonomic diversity being high in all samplings dates (Table 3 ). In terms of density, the collector-filterers were the most dominant group during 2012, although, during 2013, the shredders and grazers were dominant (Figure 3C).

Canonical correspondence analysis (CCA) showed that total dissolved solids (TDS) $(F=$ 3.33, $P=0.09)$ and $\%$ coarse sand ash $(F=3.46$, $P=0.048$ ) were the variables that best explained variability of axes in the abundance analysis $(80 \%)$. In Acantuco and La Estacada total abundances were explained by the NTU's, whereas for Castilla, the farthest stream from the volcano, abundances were in 2012 positively explained by TDS (Figure 4A). The greater richness of taxa was associated with high values of TDS (Figure 4B). Moreover, the abundance of taxa in some functional groups (e.g. collectors-filterers) was in general associated with TDS, whereas the abundance of predator taxa were associated with increased turbidity (NTU).

\section{DisCUSSION}

After the eruption of the Puyehue-Cordón Caulle volcanic complex, and as reported in other studies (Miserendino et al. 2012), the major immediate environmental changes observed were related to the vast amount of ash ejected and deposited in the nearby area. The most significant adverse effects were changes in stability related to habitat destruction, damming, flashfloods, destruction of channels and the formation of new ones, as well as changes in water quality. Conductivity, TDS, $\mathrm{pH}$, and turbidity increased sharply after the eruption. All these variables changed due to the ash load in the streams. Miserendino et al. (2012) found that TDS in Chubut streams was the variable that better reflected the ash fall effect of the Chaitén volcanic eruption in 2008. Although we did not measure ash granulometry, it was evident that a fraction of the fallen ash corresponded to coarse sand like particles that obliterated the bottom habitat; another lighter fraction was responsible for high turbidity (i.e. NTU values) in summer 2012. In 2013, the NTU values decreased markedly in all sampled streams being close to those observed in Casa de Piedra (NTU ${ }_{2013}=$ 0.22 ), a nearby stream which was not affected by the eruption. This could reflect cleansing of the stream by natural runoff with time. Another issue is that conductivity and TDS are closely correlated and can be influenced by pre-existing conditions. This would be the case for Castilla where conductivity and TDS pre-volcanic values were higher than in the two other streams, probably because Castilla originates in a wetland which normally increases the values for these two variables (Perotti et al. 2005). It seems reasonable to predict that natural runoffs will continue to clean the streams, and, eventually, they will return to similar pre-eruptive conditions. However, the recovery time will vary in relation to differential ash fall fractions and 
deposited amounts, drainage areas, ash transport to stream channel, stream slope, flow regime and other hydrological and climatological characteristics. Although turbidity will probably continue to decrease rapidly as the lighter ash fractions are washed away, removal of coarse sand like ash deposits will vary depending of slope and flow as it can be seen from the differential removal experienced in the three studied streams (Table 2).

The main effect of the ash was the decrease of benthic fauna, which serves as food for fish and other organisms. It is worth to point out, that in both Acantuco and La Estacada, the absence of both, benthic and drift fauna recorded, was absolute immediately after the eruption (Vigliano et al. 2012). Most notably, it was a decrease in specimens per $\mathrm{m}^{2}$ and a lower the number of taxonomic groups present in these two streams six months after the eruption with regards to those 18 month later. This is suggestive and in agreement with studies elsewhere in the world (Anderson 1992; Dorava \& Milner 1999), and also with data from other streams affected by other volcanic events in Patagonia (Miserendino et al. 2012). Some authors have found that the impact of ash fall on benthic fauna is higher in smaller streams with low flows (Death et al. 2003; Miserendino et al. 2012). However, our data do not allow to verify this issue because Castilla, the smallest studied stream with respect to flow and discharge, was also the less affected by the ash fall maintaining high density and diversity of organisms, with values comparable to those of other studies in the Andean zone (Navone 2006; Buria 2007). Probably, among the causes for this, are the smaller amounts of ash deposited in its watershed (Figure 1) and a lower proportion of coarse sand ash like particles with regards to those of the streams nearer to the volcanic center (Gaitán et al. 2011).

The survival of benthic fauna would be modulated by the amount of ash fall and fallen particle size fractions. In Acantuco, the stream closest to the volcano, with $15-30 \mathrm{~cm}$ of ash deposit and a $98 \%$ of coarse sand particles, benthic habitats were obliterated, destroying most of the benthic fauna. In La Estacada there were $7.5-10 \mathrm{~cm}$ of ash deposit with a $60 \%$ of coarse sand ash like particles, and not all benthic habitats were destroyed, allowing for some refuge availability. Whereas, in Castilla ash and coarse sand particles did not accumulate as in the other streams allowing for more habitat availability and therefore even a higher survival of benthic organisms.

Although the present study was focused at family level, it allowed the characterization of the benthic fauna inhabiting different sites by the assessment of the presence and importance of different taxa. The most numerous family was the Chironomidae, which was present in the three streams along with the Leptophlebidae. In 2012, the high numbers of Chironomidae in the two most heavily impacted streams (i.e. Acantuco and Estacada) are similar to what has been reported for Mt. Saint Helens, where high Chironomidae densities were associated to highly impacted streams (Edwards \& Sugg 2005). On the other hand, the densities of Chironomidae in Castilla in 2012 were as low as to those found by Miserendino et al. (2012) in streams disturbed by Chaiten's ash fall. This suggests that Chironomidae, being of short life cycle, may be good colonizers of highly impacted habitats as suggested by Collier et al (2002) for a stream disturbed by lahars. The presence of Leptophlebidae in all sampling sites and dates and Elmidae in Acantuco in 2012 is hard to explain because these two groups are usually considered good water quality indicators (Cota et al. 2002; Miserendino 2007). This apparent contradiction might be due to their short life cycles, their variety of recolonization strategies (Carvalho \& Uieda 2006) or because they are less susceptible to ash fall than to other types of water quality detrimental effects.

The orders Trichoptera and Plecoptera are a common component of the benthic assemblages in Andean streams (Buria 2007). Eighteen months after the eruption, the order Trichoptera was still absent from Acantuco and Estacada, as so were the Plecoptera in Acantuco. Misserendino et al. (2012) found that the Trichoptera were the most affected by volcanic ash in the Chaitén eruption in 2008. Recolonization depends on two factors, availability of reproductive adults and habitat suitability for larval establishment and survival. Arrival of adults will depend on their intrinsic dispersal capability, the extension and severity of the impact and/or the existence of refuges that may shelter individuals, later becoming dispersion centers (Dale et al 2005). Extensive high impact eruptions may reduce the availability of adults and increase the time lag for reintroduction. A quick recovery may also depend on the mobility of adult 
specimens; which seems to be the case for Baetidae mayflies and Chironomidae midges after floods (Robinson 2003). On the other hand, if the habitat is not suitable for egg laying, larval establishment and survival the environment would act as a filter that would impede recolonization (Tonn 1990). According to Anderson (1992), this was the effect of ash fall with regards to Trichoptera larvae in streams of the northwestern Pacific.

Volcanic events can easily destroy the trophic web through the destruction of the food base. In this sense, the variables that best explain the variation in the relative abundances of the found taxa in the nearest streams were turbidity and proportion of coarse sand ashlike particles. Disappearance of organisms can result from habitat burial and/or abrasion of bottom surfaces by coarse ash particles. Furthermore, turbidity is a reflection of suspended small size ash particles in the water which can be deadly for small organisms if ingested (Wolinski et al. 2013).

Environmental variations due to ash transport seemed to have determined the variation in the taxonomic and functional feeding groups found in each sampling date. Collector-gatherers are dominant in temperate zones, in terms of abundance and biomass (Whol et al. 1995; Lemly \& Hildebrand 2000). However, catastrophic events induce changes that depend on the impact level. Functional groups in the studied streams seem to reflect two different scenarios. In the two most impacted streams (Acantuco and Estacada) several functional groups have temporarily disappeared, and collector-gatherers remained dominant. On the other hand, all functional groups were present in the less impacted stream (i.e Castilla), although in densities that do not correspond to those usually reported for temperate streams (Vanotte et al. 1980, Velásquez \& Miserendino 2003; Miserendino 2004; Navone 2006).

Two years after the eruption, benthic organisms density, number of species and proportions of functional groups, as well as the EPT and BMPS indexes, compared to values from non impacted streams in Patagonia (Miserendino 2004, Navone 2006, Buria 2007), suggest that in both streams the trophic web has not fully recovered yet. The recovery of the trophic webs can take from a few months to several years depending on the intrinsic characteristics of each environment and the degree of impact (Anderson 1992; Dorava \& Milner 1999; Collier et al. 2002).

Volcanism in the region is a frequent phenomenon (Vigliano et al. 2011) and is considered one of the structuring forces of its present flora and fauna (Ruzzante \& Rabassa 2011). Thus the flora and fauna of the region evolved, survived and thrived despite a history of episodic volcanic events. The Cordón Caulle-Puyehue formation itself has a history of cyclic eruptions approximately every 50 years (Singer et al. 2008). These types of events cause the demise of benthic organisms by direct death or by habitat destruction or alteration (i.e. obliteration and or abrasion) which erodes the trophic food web. Benthic organisms have mechanisms of environmental recolonization after the occurrence of frequent catastrophic disturbances (i.e. flashfloods and droughts, Mundahl \& Hunt 2011). This type of mechanisms allows recolonization as habitat conditions slowly improve. Continued monitoring of the streams would allow for a better understanding of the process in the long run, not in relation to volcanic events only, but also with regards to other natural or anthropogenic causes of disturbance.

ACKNOWLedgements. This study was financed through the Programa Científico-Tecnológico de apoyo a la emergencia de la erupción del volcán Puyehue (PROEVO 2012) as well as by Technical Cooperation agreement with the Legislature of the Province of Neuquén and the Universidad Nacional del Comahue. We thank to $G$ Mariluan for helping in solving taxonomic problems, A Veleizán for helping with use of CANOCCO program and D Kent for reviewing our English.

\section{REFERENCES}

Albariño, RJ. 1994. Análisis de la fracción macrozoobéntica de un cuerpo lótico andino. Tesis de Licenciatura. CRUBUNComahue. Argentina. 66p.

ANDERSON, NH. 1992. Influence of disturbance on insect communities in Pacific Northwest streams. Hydrobiol., 248: 79-92.

AnNen, C \& JJ Wagner. 2003. The impact of volcanic eruptions during the 1990s. Nat. Hazards., 4: 169-75.

Antos, JA \& DB ZoBel. 2005. Plant responses in forests of the tephra-fall zone. p. 47-58. In: Dale VH, Swanson FJ, Crisafulli CM, (eds). Ecological responses to the 1980 eruption of Mount St. Helens. New York, NY: Springer.

Arendt, W; D Gibbons \& G Gray. 1999. Status of the volcanically threatened Montserrat Oriole Icterus oberi and other forest birds in Montserrat. West Indies Bird Conserv. Int., 9:351-372.

Armitage, PD; D Moss; JF Wright \& MT Furse. 1983. The performance of a new biological water quality score system based on macroinvertebrates over a range of unpolluted running water sites. Water Res., 17:333-47.

Beamud, G; M Diaz; GD Baffico; PF Temporetti \& FL 
Pedrozo. 2012 Calidad de aguas en la zona del complejo volcánico Cordón Caulle de Junio de 2011. En Informe de Avance Efectos de la Caída de Cenizas del Complejo Volcánico Puyehue (CPCC) Sobre la Región del Lago Nahuel Huapi. Convenio de Asistencia Técnica Centro Regional Universitario Bariloche (Universidad Nacional del Comahue). Legislatura del Neuquén. Mayo 2012. $142 \mathrm{pp}$.

BesOAIN, ME. 1985. Los suelos. In: Suelos volcánicos de Chile. J. Toso. Santiago de Chile, Instituto Investigaciones Agropecuarias (INIA), Ministerio de Agricultura, pp 25-106.

BURIA, LM. 2007. Efecto de la depredación en la estructuración comunitaria del zoobentos en ambientes lóticos Norpatagónicos. Tesis Doctoral. Universidad Nacional del Comahue-CRUB. Argentina. 188 pp.

Buteler, M; T Stadler, GP López García; MS Lassa; D Trombotto Liaudat; P D'adamo et al. 2011. Propiedades insecticidas de la ceniza del complejo volcánico PuyehueCordón Caulle y su posible impacto ambiental. Rev. Soc. Entomol. Argent., 70:149-156.

Caneiro, A; L Mogni, A Serquis, C Cotaro, D Wilberger et AL. 2011. Análisis de cenizas volcánicas Cordón Caulle. Informe Cenizas Volcánicas. Comisión Nacional de Energía Atómica Junio de 2011. 7 pp.

Carignano, L \& C Ravasi. 2011. Análisis físico químico Aguas de suministro de agua potable Cenizas Volcán Puyehue. INVAP División Ingeniería de Procesos C289CCAA-9IPCA-006-A- 5pp.

Carrera, C \& K Fierro. 2001. Manual de monitoreo. Los macroinvertebrados acuáticos como indicadores de la calidad del agua. Editorial Eco Ciencia. Quito, Ecuador. $67 \mathrm{pp}$.

Carvalho, EM \& VS Uieda. 2006. Colonization routes of benthic macroinvertebrates in a stream in southeast Brazil. Acta. Limnol. Bras., 18:367-376.

Collier K; S Parkyn; J Quinn \& M Scarsbrook. 2002. Bouncing back: how fast can stream invertebrates recolonise?. Water \& Atmosphere NIWA, 10:9-11.

Cota L; M Goulart; P MOReno \& M Callisto. 2002. Rapid assessment of river water quality using an adapted BMWP index: a practical tool to evaluate ecosystem health. Verh Internat Verein Limnol., 28:1-4.

Dale, VH; FJ Swanson \& CM CRisafulli. 2005. Disturbance, survival, and succession: understanding ecological responses to the 1980 eruption of Mount St. Helens. p. 3-11.In: VH Dale; FJ Swanson, CM Crisafulli (eds). Ecological responses to the 1980 eruption of Mount St. Helens. New York, NY: Springer.

Death, RG; BR Baillie \& P Fransen. 2003. Effect of Pinus radiata logging on stream invertebrate communities in Hawke's Bay, New Zealand. NZ J. Ma.r Freshw. Res., 37:507-20.

Del Moral, R \& Y Grishin. 1999. Volcanic disturbances and ecosystem recovery16; 137-160 Pp. In: LR Walker (ed.). Ecosystems of disturbed ground, ecosystems of the world. Elsevier Publishers.

Del Moral, R. 1981. Life returns to Mount St. Helens. Nat. Hist., 90:36-49.

Domínguez, E \& HR, Fernández (Eds.). 2009. Macroinvertebrados bentónicos sudamericanos. Sistemática y biología. Fundación Miguel Lillo. Tucumán, Argentina. 654 pp

DORAVA, JM \& AM MiLnER. 1999. Effects of recent volcanic eruptions on aquatic habitat in the Drift River, Alaska implications at other Cook Inlet region volcanoes. Environ. Manage., 23: 217-30.

EdWARdS, JS; R CRAWFord; PM SUgG \& MA Peterson. 1986. Arthropod recolonization in the blast zone of Mount St. Helens. pp. 329-333. in: SAC. Keller (Ed.). Mount St. Helens: Five years later. Eastern Washington State University Press, Cheney, Washington.

EDWARDS, JS \& PM SUGG. 2005. Arthropods as pioneers in the regeneration of life on the pyroclastic-flow deposits of Mount St. Helens. in: VH Dale, Swanson FJ, Crisafulli CM, (Eds). Ecological responses to the 1980 eruption of Mount St. Helens. New York, NY: Springer: 27-138.

Gaitán, JJ; JA Ayesa; F Umaña; F Raffo \& DB Bran. 2011. Cartografía del área afectada por la ceniza del volcán Puyehue en Río Negro y Neuquén. Informe PROEVO.

Gaitán, JJ; JA Ayesa; F Umaña; F RAFFo \& DB Bran. 2012. Cartografía del área afectada por la ceniza del volcán Puyehue en Río Negro y Neuquén. XIX Congreso Latinoamericano de la ciencia del suelo, XXIII Congreso Argentino de la ciencia del suelo.

GRAY, LJ. 1989. Emergence production and export of aquatic insects from a tall grass prairie stream. Southw. Nat., 34: 313-318.

Gray, LJ. 1993. Response of insectivorous birds to emerging aquatic insects in riparian habitats of a tall grass prairie stream. Am. Midl. Nat., 129: 288-300.

Hufner, R \& C Osuna. 2001 Caracterización de muestras de cenizas volcánicas Volcán Puyehue. Informe INVAP División Ingeniería de Procesos C289-CCGG-9IPCA001-A. 5pp.

HuRlbert, ST. 1984. Pseudoreplication and the design of ecological experiments. Ecol. Monogr., 54:187-211.

JACKSON, JK \& SG FISHER. 1986. Secondary production, emergence and export of aquatic insects of a Sonoran stream. Ecology, 67:629-638.

JCKEL, K. 1986. Finite sample properties and asymptotic efficiency of Monte Carlo tests. J. Appl. Econom., 14: 85-118.

Lallement, ME; GE Lippolt; SM Juarez; PH Vigliano \& MA DenEGRI. 2012. Efecto de la erupción del complejo volcánico Puyehue-Cordón Caulle sobre arroyos de la cuenca del N. Huapi. $5^{\circ}$ Congreso Argentino de Limnología. Santa Fe. Argentina.

LEMLY, AD \& RH HiLDEBRAND. 2000. Influence of large woody debris on stream insect communities and benthic detritus. Hydrobiol., 114:195-203.

MARSKe, KA; MA IVIE \& GM Hilton. 2007. Effects of volcanic ash on the forest canopy insects of Montserrat, West Indies. Environ. Entomol., 36:817-25.

Martin, RS; SFL Watt; DM Pyle; TA Mather; NE MATTHEWS; RB GeORG; ET AL. 2009. Environmental effects of ashfall in Argentina from the 2008 Chaitén volcanic eruption. J. Volcanol. Geotherm. Res., 184:462-72.

Masciocchi, M; AJ Pereira; MV Lantschner; JC Corley. 2013. Of volcanoes and insects: the impact of the Puyehue-Cordon Caulle ash-fall on populations of invasive social wasps, Vespula spp. Ecol. Res., 28:199205.

MerRIt, RW\& KW Cummins. 1978. An introduction to the aquatic insects of North America. Kendal Hunt Publishing Co. 440 pp.

Miserendino, ML \& LA Pizzolón. 1999. Rapid assessment of river water quality using macroinvertebrates: a family level biotic index for the Patagonic Andean zone. Acta. 
Limnol. Bras., 11:137-148.

Miserendino, ML \& LA Pizzolón. 2000. Macroinvertebrates of a fluvial system in Patagonia: altitudinal zonation and functional structure. Arch. Hydrobiol., 150:55-83.

Miserendino, ML. 2004. Effects of landscape and desertification on the macroinvertebrate assemblages of rivers in Andean Patagonia. Arch. Hydrobiol., 159: 185-209

Miserendino, ML. 2007. Macroinvertebrate functional organization and water quality in a large arid river from Patagonia (Argentina). Ann. Limnol., 43:133-145.

Miserendino, ML; M Archangelsky; C Brand; L Beltrán Epele. 2012. Environmental changes and macroinvertebrate responses in Patagonian streams (Argentina) to ashfall from the Chaitén Volcano (May 2008). Sci. of Tot. Envi., 424:202-212

Modenutti, BE; EG, Balseiro; J Elser; M Bastidas Navarro; F CuAssolo ET AL. 2013. Effect of volcanic eruption on nutrients, light, and phytoplankton in oligotrophic lakes. Limnol. Oceanogr., 58:1165-1175

MundaHL, ND \& AM HunT. 2011. Recovery of stream invertebrates after catastrophic flooding in southeastern Minnesota, USA. J. Freshw. Ecol., 26:445-457.

Navone, G; M Alonso \& P Macchi. 2006. Distribución y uso del habitat de la Ictiofauna en el río Pichi Leufu. Tesis de Licenciatura. CRUB-UNCo, Argentina.118p

ÓsKarsSON, N. 1980. The interaction between volcanic gases and tephra: fluorine adhering to tephra of the 1970 Hekla eruption. J. Volcanol. Geotherm. Res., 8:251-266.

Paruelo, JM; EG Jobbagy \& OE Sala .1998. Biozones of Patagonia (Argentina). Ecol. Austral, 8:145-153.

Perotti, MG; MC DiéGuez \& FG Jara. 2005. Estado del conocimiento de humedales del norte patagónico (Argentina): Aspectos relevantes e importancia para la conservación de la biodiversidad regional. Rev. Chil. His. Nat., 78:723-737.

REDDING, JM; CB SCHRECK \& FH EVEREST. 1987. Physiological Effects on Coho Salmon and Steelhead of Exposure to Suspended Solids. T. Am. Fish. Soc., 116: 737-744.

Robinson CT; U Uehlinger \& MT Monaghan. 2003. Effects of a multi-year experimental flood regime on macroinvertebrates downstream of a reservoir. Aquat. Sci., 65:210-222.

Ruzzante, DE \& J Rabassa. 2011. Paleogeography and Paleoclimatology of Patagonia: Effects on biodiversity. Biol. Journ. Lin. Soc., 103:221-228.

SINGER, BS; BR Jicha; MA HARPER; JA NARANJO; LE LARA \& H. Moreno-RoA. 2008. Eruptive history, geochronology, and magmatic evolution of the Puyehue-Cordón Caulle volcanic complex, Chile. Geol. Soc. Am. Bull., 120:599618.

Ter BraAk, CIF \& P Smilauer. 1998. CANOCO Reference manual and User's guide to Canoco for Windows: software for Canonical Community Ordination (version 4). Microcomputer power, Ithaca. NY $357 \mathrm{pp}$.

TonN, WM. 1990.Climate Change and Fish Communities: A Conceptual Framework. Trans. Amer. Fish. Soc., 119: 337-352.

VELÁSQUEZ, SM \& ML MisERENDINO. 2003. Habitat type and macroinvertebrate assemblages in low order Patagonian streams. Arch. Hydrobiol., 158:461-83.

Vigliano, PH; A Jones; A Judd; H Planas; G Lippolt. 2011. Bottom gas seeps at lake Nahuel Huapi, Patagonia. Rev. Asoc. Geol. Argentina, 68: 481-490.

Vigliano, P;P Macchi; G LiPPOLt; M Lallement; MA DenEgrI ET. AL. 2012. Evaluación de los Efectos de la Erupción del Volcán Puyehue-Cordón Caulle sobre los Ensambles de Peces de Arroyos del Norte de Patagonia". Informe Final de Proyectos de Investigación F011-04. Programa de Emergencia Volcánica Secretaría de Investigación, Desarrollo y Transferencia de Tecnología, Universidad Nacional de Rio Negro 29 de Mayo de 2012. 8pp.

Villarosa G; V Outes; A Hajduk; E Crivelli Montero; D Sellés; M Fernandez \& E CRIVElli. 2006. Explosive Volcanism during the Holocene in the upper Limay river basin: the effects of ashfall on human society. Northern Patagonia, Argentine. Quat. International, 158:44-57.

Whol, DL, JB Wallace \& J Meyer. 1995. Benthic macroinvertebrate community structure function and production with respect to habitat type, reach and drainage basin in the southern Appalachians (U.S.A). Freshwater Biol., 34:447-464.

Wilson, T; C Stewart; H Bickerton; P Baxter; V Outes; G Villarosa \& E Rovere. 2012. The health and environmental impacts of the June 2011 PuyehueCordón Caulle volcanic complex eruption. GNS Science Report.

Wiederholm, T. 1984. Responses of aquatic insects to environmental pollution. in: Resh, VH DM Rosenberg (Eds.). The ecology of aquatic insects. New York: Praeger. Pp. 508-557.

Witham, CS; C OpPenheImer \& CJ Horwell. 2005. Volcanic ash-leachates: a review and recommendations for sampling methods. J. Volcanol. Geotherm. Res., 141: 299-326.

Wolinski, L; C Laspoumaderes; M Bastidas Navarro; B. Modenutti \& E Balseiro. 2013. The susceptibility of cladocerans in North Andean Patagonian lakes to volcanic ashes. Fresh. Biol., 58:1878-1888. 